\title{
Shining a Light on Leadership in Canadian Nursing Education / Lumière sur le leadership dans la formation en sciences infirmières au Canada
}

Florence Myrick

amyrick@ualberta.ca

Jacinthe I. Pepin

Université de Montréal, jacinthe.pepin@umontreal.ca

\section{Recommended Citation}

Myrick, Florence and Pepin, Jacinthe I. (2016) "Shining a Light on Leadership in Canadian Nursing Education / Lumière sur le leadership dans la formation en sciences infirmières au Canada," Quality Advancement in Nursing Education - Avancées en formation infirmière: Vol. 2: Iss. 2, Article 8.

DOI: https://doi.org/10.17483/2368-6669.1106

This Interview is brought to you for free and open access by Quality Advancement in Nursing Education - Avancées en formation infirmière. It has been accepted for inclusion in Quality Advancement in Nursing Education - Avancées en formation infirmière by an authorized editor of Quality Advancement in Nursing Education - Avancées en formation infirmière. 


\section{Shining a Light on Leadership in Canadian Nursing Education}

Interviewee: Dr. Deborah Tamlyn, Past President, Canadian Nurses Association, Past President, Canadian Association of Schools of Nursing, Former Dean, Faculty of Nursing, University of Calgary, Former Director, School of Nursing, Dalhousie University, Former Vice-Dean, Faculty of Health Professions, Dalhousie University

Interviewer: Dr. Florence Myrick, Co-Editor-inChief

Dr. Myrick: First of all, Dr. Tamlyn, before we begin, I would like to take this opportunity on behalf of Dr. Jacinthe Pepin, my Co-Editor-in-Chief, and myself to thank you for agreeing to take the time for this interview. Thank you very much.

Dr. Tamlyn: Yes, I am pleased to be involved.

Dr. Myrick: I would like to begin by acknowledging that over the course of your career, you have assumed many, and I underscore the word many, leadership roles in nursing education throughout Canada. In light of your experience within that leadership context, what would you say are some of the major changes you have witnessed?

Dr. Tamlyn: In giving some thought to this question, what immediately comes to mind is the growth or expansion in the number of baccalaureate and graduate nursing programs and the increased number of graduates from these programs. Most registered nurses in Canada have now completed their programs through a university or a university-college partnership. The enrolments and the number of students with whom degree prepared educators are now involved has created a much more cohesive and integrated network. I remember when I was president in the early nineties we changed our constitution to include representatives from all colleges to be voting members within CASN (then called CAUSN). This decision was an important step in promoting inclusiveness and the engagement of a growing network of nurse educators, which continues today. In addition, over the last several decades, there has been tremendous growth in doctoral nursing programs and the many opportunities for graduates to go on to pursue post-doctoral experience. Nurse practitioner programs and other innovations such as the accelerated degree programs have also emerged.

Another important major change has been the

\section{Lumière sur le leadership dans la formation en sciences infirmières au Canada}

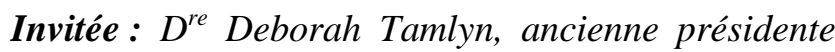
de l'Association des infirmières et infirmiers du Canada et de l'Association canadienne des écoles de sciences infirmières, elle a occupé les postes de doyenne de la Faculté des sciences infirmières de University of Calgary, directrice de l'École des sciences infirmières de Dalhousie University, et vicedoyenne de la Faculté des professions de la santé de Dalhousie University

Intervieweuse : $D^{r e}$ Florence Myrick, corédactrice en chef

$D^{\text {re }}$ Myrick : $D^{\text {re }}$ Tamlyn, avant de commencer, je tiens à vous remercier, en mon nom et au nom de la $\mathrm{D}^{\mathrm{re}}$ Jacinthe Pepin, corédactrice en chef, de prendre le temps de nous accorder cette entrevue. Merci infiniment.

$D^{\text {re }}$ Tamlyn : Je suis ravie d'y prendre part.

$D^{\text {re }}$ Myrick : Je voudrais commencer en précisant qu'au cours de votre carrière, vous avez eu plusieurs, et je souligne le mot plusieurs, rôles de leadership dans la formation en sciences infirmières à la grandeur du Canada. À la lumière de vos expériences, quels sont certains des plus grands changements dont vous avez été témoin?

$D^{\text {re }}$ Tamlyn : En y réfléchissant, la première chose qui me vient en tête est l'augmentation du nombre de programmes de baccalauréat et d'études supérieures en sciences infirmières, ainsi que l'augmentation du nombre de diplômées de ces programmes. La plupart des infirmières autorisées au Canada ont complété leur programme dans une université ou bien grâce à un partenariat collège-université. Les inscriptions et le nombre d'étudiantes dont les enseignantes sont formées aux cycles supérieurs ont permis de créer un réseau beaucoup plus cohésif et intégré. Je me souviens, lorsque j'étais présidente au début des années 90, nous avions modifié notre constitution pour que des représentantes de tous les collèges soient membres votants au sein de l'ACESI (alors appelée l'ACEUN). Cette décision fut une étape importante dans la promotion de l'inclusion et de l'engagement d'un réseau grandissant d'infirmières enseignantes, des actions qui se poursuivent encore aujourd'hui. De plus, au cours des quelques dernières décennies, nous avons vu une forte augmentation du nombre de programmes de doctorat en sciences 
diversity and richness of faculty who are involved in the delivery of the programs. Working in partnership with colleagues employed by a university or a college has not been without its challenges-challenges related to working under different collective agreements, which sometimes inhere differences in missions or mandates in our home or parent institution. One area we have had to consider is expanding our view of scholarship. CASN has provided leadership in that area by providing a more inclusive view using Boyer's model. As well, in the university, we have seen a decrease in the number of tenured or tenure-track positions, a very significant development. Such positions serve to safeguard a certain percentage of time for faculty members to engage in scholarship and research. What we experience today is a decreased percentage of faculty who are tenured. There are more limited-term appointments, which are primarily teaching-focused. We also employ a large number of part-time or sessional faculty, sometimes seconding individuals from the clinical agencies. In turn, this alters the base of the professoriate or those faculty members who are actually engaging directly with the students, particularly the undergraduates. What we tend to see, and rightfully so, is that the $\mathrm{PhD}$-prepared and more research-engaged faculty are assigned to work with the graduate programs, which means that, in our undergraduate programs, the involvement of tenuretrack faculty is considerably less than it used to be. This evolution calls for new models of teaching and learning to ensure that the presence and impute of those faculty who are engaged in research retain a bona fide presence in the undergrad programs as well.

Finally, the last development that I would mention is technology. We have really seen a growth in the amount of funding in various provinces and territories available for the establishment and use of simulation in learning and teaching. Increasingly, other health programs are also using more simulation. High-fidelity simulation is expensive, and faculty need adequate preparation to use such an approach to teaching and learning effectively. Some data suggest that the uptake or approval ratings by students with regard to simulation are not always as high as we would like to see. Invariably, we need to overcome the sense that simulation is not real, or that it is not the same as it would be in the "real world." We need considerably more research to illustrate to what infirmières et d'occasions pour les diplômées de faire un stage postdoctoral. Les programmes d'infirmières praticiennes et d'autres innovations, comme le programme accéléré, sont également apparus.

Un autre changement important est la diversité et la richesse des membres du corps professoral qui enseignent dans les programmes. La collaboration avec des collègues travaillant au sein d'universités ou de collèges n'a pas été sans heurts; nous avons dû relever des défis causés par des conventions collectives différentes, qui reflètent parfois des missions ou des mandats différents, entre nos divers établissements d'attache. Une importante considération a été l'élargissement de notre vision du scholarship. L'ACESI a été un leader dans ce secteur en offrant une vision plus inclusive à partir du modèle de Boyer. Aussi, nous avons été témoins d'une baisse du nombre de postes de carrière menant à la permanence dans les universités, ce qui constitue un changement majeur. Ces postes permettent aux professeurs de dédier une partie de leur temps au scholarship et à la recherche. Nous vivons aujourd'hui une baisse du nombre de professeurs de carrière. Il y a plus d'affectations de courte durée, qui sont surtout centrées sur l'enseignement. Nous embauchons également un grand nombre de personnes à temps partiel ou par semestre, qui viennent parfois retirer des personnes du milieu clinique. Cela a pour effet de changer la nature même du corps professoral et des personnes qui sont directement impliquées auprès des étudiantes, particulièrement ceux du premier cycle. Ce à quoi nous assistons, et avec raison, c'est une situation où les professeures détenant une préparation doctorale et engagées en recherche sont amenées à travailler davantage avec les étudiantes des programmes des cycles supérieurs; leur implication dans les programmes de premier cycle est donc moindre qu'autrefois. Cette évolution nous oriente vers de nouveaux modèles d'enseignement et d'apprentissage pour assurer une présence et un apport véritable des professeures engagées dans la recherche auprès des étudiants des programmes de premier cycle.

Finalement, le dernier changement dont je veux parler est la technologie. Nous avons vu une importante augmentation du financement disponible dans les provinces et territoires pour la mise en place et l'utilisation de la simulation dans l'enseignement et l'apprentissage. La simulation est également plus présente dans les autres programmes de la santé. La 
extent simulation is effective and in what particular teaching and learning venues it works best. To that end, we need ongoing empirical evidence or knowledge research to ensure that it can adequately provide the same or better results.

An area in which we have been very engaged as faculty, which I think is tremendous, is working with other countries in providing our educational blueprints, programs, or faculty expertise to nurse educators or nursing organizations. For example, CASN has been involved in the accreditation process in many countries. I think we have seen increased global involvement through our linkages with nursing colleagues in countries such as the United States, Great Britain, and further afield in the Middle East and Asia.

Dr. Myrick: Just changing the focus, and in keeping with the theme of leadership, I am wondering now if you could share with us what you perceive to be the most important values a leader can bring to their position.

Dr. Tamlyn: I agree with the literature that a primary value is personal and professional integrity and a desire to overcome mediocrity: to change things for the better. Leadership entails relationships that serve to motivate us to achieve goals that can enhance nursing practice and patient care outcomes. Our code of ethics clearly describes what ethical leadership and ethical nursing practice is. I think integrity is extremely important because as we engage in a health care system that has assumed a more corporate or managerial approach, a business approach if you will, which, in turn, can challenge our core values in providing health care. In this model, health care is viewed often as health service - not that service is a bad word, but it tends to take the emphasis away from the caring.

A core value of leadership is respect for people. Respect in nursing education also implies that we respect each other as educators, regardless of the institution in which we are working or its primary mandate, be it teaching, research, or both. It also implies that we respect our colleagues who work in our labs, our staff, and so on, and ultimately respect for the students. Most especially, how we generate or model a culture of respect in our educational environment is critical to ensure that our graduates also emanate such respect when they engage in clinical practice, whether locally or internationally. simulation haute-fidélité coûte cher et les membres du corps professoral ont besoin de préparation afin d'utiliser efficacement une telle approche. Des données suggèrent que l'adhésion des étudiants et leur taux d'approbation quant à la simulation ne sont pas aussi élevés que nous ne l'aimerions. Assurément, nous devons dépasser le sentiment que la simulation n'est pas réelle, ou qu'elle est différente de ce qui se trouve dans la réalité. Nous avons besoin de plus de recherches pour montrer jusqu'à quel point la simulation est efficace et déterminer dans quels contextes elle fonctionne le mieux. Pour cela, il nous faut poursuivre des études qui fourniront des données de recherche et des résultats probants afin d'assurer que la simulation peut résulter en apprentissages similaires ou supérieurs à ceux de l'enseignement traditionnel.

L'un de nos engagements, que je trouve formidable, est celui de travailler en collaboration avec d'autres pays en partageant nos modèles de formation, nos programmes ou l'expertise de notre corps professoral avec des infirmières formatrices et des organisations en sciences infirmières. Par exemple, l'ACESI a été impliquée dans le processus d'accréditation de programmes dans plusieurs pays. Je crois que nous avons renforcé notre implication mondiale grâce à nos liens avec des collègues infirmières de divers pays comme les États-Unis, la Grande-Bretagne, ainsi que d'autres pays du Moyen-Orient et d'Asie.

$D^{\text {re }}$ Myrick Changeons d'orientation, mais toujours en lien avec le thème du leadership, quelles sont selon vous les valeurs les plus importantes qu'une leader puisse apporter dans ses fonctions?

$D^{\text {re }}$ Tamlyn : Je suis d'accord avec les écrits qui affirment qu'une des valeurs les plus fondamentales est l'intégrité personnelle et professionnelle, ainsi qu'un désir de surpasser la médiocrité pour arriver à améliorer les choses. Le leadership engendre des relations qui nous motivent à atteindre des objectifs pouvant améliorer la pratique infirmière et les résultats pour les patients. Notre code d'éthique décrit clairement ce que sont un leadership éthique et une pratique infirmière éthique. Je crois que l'intégrité est extrêmement importante, car lorsque nous nous impliquons dans un système de santé qui est devenu plus « business » ou administratif au fil du temps, nos valeurs fondamentales d'offrir des soins de santé sont mises au défi. Dans ce modèle, les soins de santé sont vus comme un service de santé; ce n'est 
A value I also think important is the pursuit of excellence. Such pursuit means to strive for excellence with students and endeavour, to the extent that we can, to empower and provide opportunities for faculty to achieve their best. Subsequently, when we engage in clinical practice, to strive to overcome a tendency that exists sometimes to move towards mediocrity. We really need to set our standards high. The work carried out by RNAO with regard to their best practice guidelines is a prime example whereby you bring knowledgeable and expert people together to generate well-researched documents and guidelines, which, in turn, people in practice can use as a guide to strive for excellence.

The last point that I would make relates to the pursuit of wisdom and open-mindedness. I think openmindedness is very important because there are so many competing priorities. There is so much change that is occurring. There is great diversity among Canadian citizens and the face of who we are as our society rapidly changes. Whether it is sexual orientation, ethnic or language diversity, etc., we need to possess an open-mindedness about people and the limits of our own understanding. Research changes our practice and we need to make change when the evidence is clear. We need to be able to move forward and not feel like we have arrived. Open-mindedness refers to the approach we need to embrace with students and life-long learning, and as faculty and learners ourselves.

In addition, I use the word wisdom because we live in an information age, one in which we are constantly bombarded with so much information that sometimes we are unable to see the big picture. How do we assume a more reasoned and philosophical outlook rather than always being in a reactive or crisis mode, extinguishing fires, or trying to ascertain where the next dollar is going to come from? How do we draw on wisdom with regard to those issues that are worth fighting to preserve and those that we should let go? I think that respect for people, pursuit of excellence, and wisdom and open-mindedness are key.

Dr. Myrick: We often hear reference to the difference between leadership and management, or between the role of a leader and that of a manager. How would you respond to such a description?

Dr. Tamlyn: In keeping with the literature, what I have come to value or appreciate in regard to the difference among positional leaders, administrators, pas que le mot «service» soit mauvais, mais il a tendance à mettre l'accent ailleurs que sur le caring.

Une autre valeur fondamentale du leadership est le respect des autres. En sciences infirmières, le respect implique aussi de se respecter l'une l'autre en tant que formatrices, peu importe l'établissement dans lequel nous travaillons ou son mandat principal, que ce soit l'enseignement, la recherche, ou les deux. Cela demande aussi de respecter nos collègues qui travaillent en laboratoire, notre personnel de soutien, et, ultimement, respecter les étudiantes. Plus particulièrement, la façon dont nous générons ou modelons une culture du respect dans notre environnement éducatif assure que les diplômées dégageront aussi ce même respect lorsqu'elles commenceront leur pratique clinique, que ce soit localement ou à l'échelle internationale.

Une autre valeur que je crois importante est la poursuite de l'excellence. Ceci exige de viser l'excellence avec les étudiantes et de tenter, autant que possible, d'outiller le corps professoral et de donner à ses membres la chance de réaliser leur plein potentiel. Ainsi, lorsque nous nous impliquons dans la pratique clinique, il s'agit de tenter de surmonter la tendance à la médiocrité que l'on retrouve parfois. Nous devons établir des standards élevés. Le travail effectué par l'Association des infirmières et infirmiers autorisés de l'Ontario (la RNAO) par rapport à leurs guides de meilleures pratiques est un bon exemple, car il souligne la collaboration de personnes compétentes et expertes qui produisent des guides bien documentés, fondés sur la recherche, qu'en retour les cliniciennes peuvent utiliser dans leur pratique pour atteindre l'excellence.

Le dernier point que je veux soulever est en lien avec le développement d'une sagesse et d'une ouverture d'esprit. Je crois que l'ouverture d'esprit est très importante, car nous devons jongler avec maintes priorités et de façon constante. Les changements se multiplient. On retrouve une grande diversité parmi les citoyens canadiens, et le visage de notre société change rapidement. Que ce soit l'orientation sexuelle, l'ethnie ou la langue, nous devons rester ouverts d'esprit envers les autres et demeurer conscients des limites de notre compréhension. La recherche change notre pratique et nous devons faire des changements lorsque les preuves sont claires. Nous devons être capables d'aller de l'avant plutôt que d'avoir le sentiment d'être au bout du parcours. L'ouverture 
and managers is that managers tend to be responsible for focusing on the bottom line. They are primarily concerned with resources available to achieve the work, not to exceed those resources, and to monitor whether there is any variance. Managers are required to contend with the day-to-day and week-to-week issues, and the crises that may or do occur. They have to consider the potential for work stoppages or building code violations and their effect on the workplace while always remaining focused on risk assessment and quality assurance.

While a leader may be involved with some of the same roles and functions, very often, depending on their position within the organization, they can delegate that responsibility to the managers. Leaders tend to focus more on the future. In other words, their view plane is the horizon beyond the current day; they endeavour to take an organization from where it is today or this year and make it a better place. Moreover, they strive for enhancement, improvement, and excellence. To be effective while they remain engaged, they are not distracted or consumed by the burning issues or crises of today. They focus on planning towards the future place where they want to be. They consider resources from a different perspective. The managers take into account what constitutes the budget, the number of FTEs, the number of staff, the need for building repairs, etc. The leaders are concerned with how to grow the capacity beyond its current state. They focus on people, how to help them grow and be more effective, more knowledgeable, and less subject to low morale or burn out. Leaders develop strategic partnerships with other organizations, sometimes across provincial and territorial lines, as well as internationally. Metaphorically speaking, they do not view the pie as being a finite number of pieces; rather, they explore how they can bake more pies. It is a different slant on things, a different perspective.

Dr. Myrick: That is an interesting metaphor.

Dr. Tamlyn: On a personal level, I believe that an individual educator, nurse, or staff member can also possess an agenda involving the pursuit of leadership. Such an agenda would focus on what they achieve in their work, and what they aspire to achieve in their career with regard to knowledge, expertise, and the kind of impact, footprint, or legacy that they leave as an individual. In other words, it is not only what people who hold formal leadership positions do, but d'esprit renvoie à l'approche que nous devons avoir envers les étudiantes et l'apprentissage tout au long de la vie, et ce, en tant que professeures et apprenantes.

De plus, j'ai parlé de sagesse, car nous vivons dans une ère d'information, dans laquelle nous sommes tellement bombardées d'informations qu'il est parfois difficile d'avoir une vue d'ensemble. Comment pouvons-nous adopter une attitude raisonnée et philosophique plutôt que de toujours être en mode réaction, à éteindre des feux, à essayer de trouver d'où proviendra le prochain financement? Comment pouvons-nous profiter de la sagesse afin de cerner les problèmes pour lesquels il vaut la peine de se battre, et ceux que nous devrions laisser tomber? Je crois que le respect des autres, la poursuite de l'excellence, la sagesse et l'ouverture d'esprit sont des éléments clés.

$D^{\text {re }}$ Myrick : Nous entendons souvent parler de la différence entre le leadership et la gestion, ou entre le rôle de leader et le rôle de gestionnaire. Qu'en pensez-vous?

$D^{\text {re }}$ Tamlyn : Dans l'esprit de ce que l'on retrouve dans la littérature, j'en suis venue à apprécier la différence entre les leaders, les administrateurs et les gestionnaires. Les gestionnaires sont souvent responsables de se centrer sur les résultats. Ils se préoccupent surtout des ressources disponibles pour accomplir le travail, de ne pas aller au-delà de ces ressources, et de surveiller s'il y a des variations. Les gestionnaires doivent s'occuper des problèmes de tous les jours, semaine après semaine, ainsi que des crises qui peuvent surgir. Ils doivent tenir compte des possibles arrêts de travail ou violations au code du bâtiment et des effets de tels événements sur le milieu de travail, tout en gardant en tête l'évaluation des risques et l'assurance de la qualité.

Bien qu'une leader puisse souvent jouer un rôle semblable et avoir des fonctions similaires, selon sa position dans l'organisation, cette responsabilité peut souvent être déléguée à des gestionnaires. Les leaders ont plutôt tendance à regarder vers l'avenir. En d'autres mots, leur point de vue est l'horizon au-delà du présent; elles s'efforcent de prendre l'organisation au point où elle en est aujourd'hui, et d'en faire un meilleur endroit. Elles s'efforcent de tendre vers le perfectionnement, l'amélioration et l'excellence. Pour être efficaces tout en restant impliquées, elles ne doivent pas se laisser distraire ou être accaparées par 
also it is what we do as an individual that also matters. Individual leadership involves personal mastery, the ability to consider work-life balance, understanding how to approach conflict, and developing relationships with positional leaders, all of which require support and education for those who actually hold positions of formal leadership. Individually, however, we need to focus so much more on the people who are actively contributing to achieving the mission, but who do not themselves necessarily hold those positions.

Dr. Myrick: In light of your experience, what do you view as being the most challenging aspect of being a leader in nursing education today?

Dr. Tamlyn: Great question. I think that one of the biggest challenges we currently face is the amount and rate of change that we are experiencing and the multiple and sometimes competing demands. As I have already said, we have expanded our enrolment, the number of our programs, and our international work. We also have in place a different kind of staffing situation. For example, we are working in partnerships across college and university institutions, thus the challenge for a leader now is team leadership. It has to be shared leadership. I might hold a leadership position, I might be dean, but my faculty and even beyond my admin team are leaders in their own right. We also have student leaders. We really need to cultivate that kind of shared leadership to move forward. The other point I would make, which relates to society more broadly and the lives of students and faculty, is the amount of stress and anxiety that people are bringing with them to the workplace. We witness, for example, the costs of education escalating to the point whereby many students hold part-time jobs. Some students are raising families or caring for their loved ones while they are acquiring their education - particularly at the graduate level. Such circumstances are extremely challenging, for example, how to maintain that worklife balance, but also educators who want to focus on the educational mission and be respectful of their students while the students are being pulled in a number of different directions, as can be faculty as well.

Dr. Myrick: So then, Dr. Tamlyn, how would you measure success as a leader?

Dr. Tamlyn: I think you measure success as a leader by being very clear about the change you want to les questions urgentes ou les crises du moment. Elles doivent planifier le futur désiré et voir les ressources d'une autre façon. Les gestionnaires tiennent compte $\mathrm{du}$ budget, du nombre d'ETP, des membres du personnel, des besoins en réparation des édifices, etc. Les leaders se préoccupent de trouver comment augmenter les capacités actuelles. Elles se concentrent sur les personnes, comment les aider à devenir meilleures et plus efficaces, mieux informées, et moins sujet à la déprime ou à l'épuisement professionnel. Les leaders développent des partenariats stratégiques avec d'autres organisations, parfois au-delà des frontières provinciales et territoriales, allant même jusqu'à l'international. Pour l'exprimer en métaphore, plutôt que de voir la tarte comme un nombre de morceaux déterminés, les leaders tentent à chercher comment faire plus de tartes. C'est un nouveau point de vue, une nouvelle manière de voir les choses.

$D^{\text {re }}$ Myrick : Voilà une métaphore intéressante.

$D^{\text {re }}$ Tamlyn : Personnellement, je crois qu'une formatrice, une infirmière ou un membre du personnel peut aussi planifier de développer son leadership. Un tel plan serait axé sur ses réalisations au travail et sur ses aspirations de carrière quant aux connaissances, à l'expertise, et aux effets, traces ou héritage qu'elle veut laisser en tant que personne. En d'autres mots, ce qui importe n'est pas seulement les actions de celles qui occupent des postes de leadership, mais également ce que nous faisons tous en tant qu'individus. Ce leadership individuel nécessite la maîtrise de soi, la capacité de trouver un équilibre travail/vie personnelle, la compréhension de la façon d'approcher un conflit et la création de relations avec celles qui sont en position de leadership; toutes des qualités qui nécessitent du soutien et une préparation de celles qui détiennent des postes de leadership. Cependant, nous devons davantage nous centrer sur les personnes qui contribuent activement à la réussite de la mission d'une organisation sans occuper un poste qui le requiert.

$D^{\text {re }}$ Myrick : Selon votre expérience, quel est le plus grand défi inhérent au rôle de leader dans le domaine de la formation en sciences infirmières aujourd'hui?

$D^{\text {re }}$ Tamlyn : C'est une excellente question. Je crois que l'un des plus grands défis que nous rencontrons actuellement est la quantité et la vitesse des changements que nous vivons, jumelées aux 
make, where your own thinking is, and what excellence looks like. Leadership is about helping people and organizations achieve great things, so as a leader you have to be ambitious. Frequently, people will say we have to be realistic, this is what we can do with the resources we have, to which there is a lot of validity, but if we do not dream big or aspire to much more, then we tend to fall short. So when you think of the mission of the academy, and I include our partners as well, it is to offer opportunities to individuals who want to pursue degrees to become leaders in their own right, to feel that they are equipped to provide excellent care, and also to be able to navigate the stormy waters of health care. In other words, to be able to swim rather than sink, to thrive and not just survive.

The other dimension of success in the university is that we are not only concerned with nursing and health care, but we are also institutions of learningwhat those institutions represent to society at large, what it means to be an educated citizen, to contribute to society, and to be able to share our knowledge from one country to another. We can measure success in many different ways, but first we have to be clear what it is we value, and not just measure that value by one yardstick, for example, not just that our enrolments have increased or that we have garnered $\mathrm{x}$ number of research dollars. It is a much broader kind of vision.

Dr. Myrick: You have already touched on my next question. If you were to identify one or two key qualities that you would target as being integral to a nurse leader, what would those be?

Dr. Tamlyn: I find this question to be an exciting but challenging one. I think the qualities that are required include clarity of vision, integrity, and courage, specifically the courage of your convictions. When I refer to courage, I am referring explicitly to the courage it takes to stay the course within a culture that may not always seem to share such values. The culture may be more focused on the managerial, the corporate or the fiscal bottom line, and not, to the same degree, on the historical and philosophical traditions of learning and what the emphasis needs to be.

Another quality is perseverance. If we believe we have the right vision and the right goals, then we have to stay the course. It does not mean we always achieve the results we want immediately, but if we multiples demandes, souvent conflictuelles. Comme je l'ai déjà dit, nous avons bonifié le recrutement d'étudiants, le nombre de programmes et nos initiatives à l'étranger. Nous vivons également un contexte de recrutement d'enseignants différent. Par exemple, nous travaillons en partenariat avec des collèges et des universités, alors le défi d'une leader est d'encadrer une équipe. Le leadership doit être partagé. Je peux me retrouver en position de leadership, je peux être doyenne, mais les professeurs et autres personnes en dehors de mon équipe administrative sont aussi des leaders. Comme le sont certaines étudiantes. Nous devons alors réellement cultiver ce type de leadership partagé pour continuer à avancer. Un autre aspect à souligner, qui se rapporte à la société en général et à la vie des étudiantes et des membres du corps professoral, est le niveau de stress et d'anxiété que les gens amènent à leur lieu de travail. Par exemple, nous sommes témoins des coûts reliés à l'éducation qui augmentent au point où beaucoup d'étudiantes doivent travailler à temps partiel. Certaines, plus particulièrement celles qui sont aux études supérieures, doivent élever une famille ou s'occuper de leurs proches tout en continuant leurs études. De telles circonstances sont très difficiles, surtout lorsque vient temps de conserver cet équilibre travail/famille. Cela est également difficile pour les professeurs qui veulent se centrer sur la mission de formation tout en respectant leurs étudiantes, alors que celles-ci se trouvent sollicitées de toutes parts, tout comme peuvent l'être les professeurs.

$D^{\text {re }}$ Myrick : Alors, $D^{\text {re }}$ Tamlyn, comment mesurezvous le succès d'une leader?

$D^{\text {re }}$ Tamlyn : Je crois que l'on peut mesurer le succès d'une leader en étant très claire à propos des changements que l'on souhaite instaurer, notre pensée, et notre vision de l'excellence. Le leadership doit aider les gens et les organisations à accomplir de grandes choses, alors en tant que leader, il faut être ambitieuse. Les gens disent souvent que nous devons être réalistes, que c'est tout ce que nous pouvons faire avec les ressources disponibles, ce qui est vrai, mais si nous ne rêvons pas assez grand et si nous n'essayons pas d'en faire plus, nous n'arriverons jamais à nos plus grands objectifs. Lorsque nous pensons à la mission de l'académie, et j'inclus ici nos partenaires, il s'agit d'offrir la chance à des personnes qui désirent poursuivre leurs études afin de devenir elles-mêmes des leaders, de sentir qu'elles 
pursue what we believe to be important, then we have to persevere.

We also, however, need to be politically savvy because we work in extremely complex institutions. We need to be knowledgeable as to how to achieve goals and how programs are actually resourced. It is important to understand the pressures in the health care system and how we can work together effectively with our colleagues. Sometimes you can encounter a situation wherein clinicians might say, "Well, why aren't those academics preparing graduates who can enter the workforce and do what they need to do right away?" It can almost seem like we do not care, respect, or have an appreciation for what is happening in those various areas. While we really need that respect to which I previously alluded, and we need to be able to communicate, we also require, as I have previously said, a lot of political savvy owing to the fact that we work in different kinds of institutions.

Dr. Myrick: In closing our interview then, what would you see as being the priority that we will be facing as future leaders in nursing education?

Dr. Tamlyn: I really like this question. I think the priority, and I say this for myself as a leader as well as for other leaders, is to focus on how to maximize creativity and optimism. When you have had a long career, and you have witnessed and achieved much, you need to be mindful of thinking outside the proverbial box, being creative and moving forward. Regarding optimism-I think for those of us who work in health care and universities, there can sometimes be a high degree of frustration, cynicism, even burn out. Thus, we need to be constantly mindful of our ability to view the glass as being half full rather than half empty, and perhaps to have some of the optimism that our students reflect. In the beginning of their careers, students often view the world as their oyster, a refreshing perspective. I think the priority and the way to achieve a sense of creativity, optimism, and a can-do attitude is through maintaining constant curiosity and life-long learning. When we learn, we derive a sense of achievement and a desire to move forward. We are so fortunate that we work in institutions of learning. Another priority is to focus on how to overcome whatever divisions there may be, whether divisions among faculty whereby some may feel more valued than others. They may have a different kind of ont les outils nécessaires pour fournir d'excellents soins, et de pouvoir naviguer dans les eaux troubles des soins de santé. En d'autres mots, de nager plutôt que de couler, de se développer au lieu de tout simplement survivre.

Il y a une autre dimension au succès à l'université. Le fait que nous ne nous occupons pas seulement des sciences infirmières et des soins de santé, mais que nous sommes des lieux d'apprentissage. Qu'est-ce que ces lieux représentent pour la société, que veux dire être une citoyenne éduquée, comment contribuer à la société et partager nos connaissances d'un pays à l'autre? Nous pouvons mesurer le succès de plusieurs façons, mais nous devons d'abord être claires quant à nos valeurs et ne pas mesurer le succès à partir d'un seul critère, par exemple le fait que nous avons augmenté le nombre d'inscriptions ou que nous avons obtenu X montant d'argent pour la recherche. Il s'agit d'une vision beaucoup plus large.

$D^{\text {re }}$ Myrick : Vous avez déjà abordé ma prochaine question. Si vous deviez identifier une ou deux qualités que vous considérez essentielles pour être une leader infirmière, quelles seraient-elles?

$D^{\text {re }}$ Tamlyn : Je trouve cette question intéressante, mais il est difficile d'y répondre. Je crois que les qualités nécessaires comprennent une vision claire, l'intégrité et le courage, plus particulièrement le courage de ses convictions. Lorsque je parle du courage, je pense explicitement au courage nécessaire pour garder le cap dans une culture qui ne semble pas toujours partager les mêmes valeurs. La culture est plutôt axée sur la gestion, sur les résultats « affaires » ou financiers, et non, au même niveau sur les traditions historiques et philosophiques de l'apprentissage ou sur ce que nous devons privilégier.

Une autre qualité est la persévérance. Si nous croyons que notre vision et nos buts sont justes, il faut garder le cap. Cela ne veut pas dire que nous serons toujours en mesure d'atteindre nos objectifs immédiatement, mais si nous voulons nous concentrer sur ce qui nous importe, il faut persévérer.

Cependant, il nous faut aussi devenir avisées politiquement, car les institutions dans lesquelles nous travaillons sont extrêmement complexes. Nous devons savoir comment atteindre nos objectifs et quelles sont les ressources dont disposent les programmes. Il est important de comprendre les pressions du système de santé et comment travailler avec nos collègues de manière efficace. Il n'est pas 
appointment and may not feel one kind is as important as another is. I also think such a perspective exists in health care as well, in particular how nurses in practice perceive nurse educators, and vice versa, and then your broader team: how nurses feel when working with educators or other practitioners. If we do not seek ways to believe in ourselves and help others to do the same, students and graduate students, to believe in themselves, and yet with a healthy dose of humility, then our energy is sapped. A term, not a new term, but one that is new to me, that I heard recently was "soul sucking." If you are participating in an activity and you cannot seem to achieve traction and cannot move forward, you lose sight of how interesting, creative, and neat things can be. You can sink into a real funk, and then your batteries just die. So that is the challenge: how do we keep the spark alive and how do we work together effectively and cohesively. These are major challenges.

Dr. Myrick: A most apropos note on which to complete our interview. Thank you for shining such an insightful light on leadership in nursing education. rare de se retrouver dans une situation où des cliniciennes disent «Pourquoi ces universitaires ne préparent-elles pas des diplômées qui peuvent entrer sur le marché du travail et faire ce qu'elles ont à faire immédiatement? » Il peut sembler que nous ne sommes pas préoccupées par ces questions, ou que nous n'avons pas de respect ou d'appréciation pour les réalités de ces secteurs. Même si nous avons réellement besoin du respect dont je parlais plus tôt, et que nous devons pouvoir communiquer, nous avons aussi besoin d'un sens politique, car nous travaillons dans des institutions différentes.

$D^{\text {re }}$ Myrick : Pour terminer cette entrevue, selon vous, quelle est la priorité à laquelle nous devrons faire face en tant que futures leaders dans le domaine de la formation en sciences infirmières?

$D^{\text {re }}$ Tamlyn : J'aime bien cette question. Selon moi, et je dis ça pour moi-même en tant que leader, mais aussi pour les autres, je crois que la priorité sera de chercher à maximiser la créativité et l'optimisme. Lorsque vous avez eu une longue carrière et que vous avez tout vu et tout fait, vous devez pouvoir penser en dehors des cadres établis, être créative et continuer à avancer. Par rapport à l'optimisme, je crois que, pour celles d'entre nous qui travaillons dans le milieu de la santé et dans les universités, il peut y avoir une grande frustration, un cynisme, ou même de l'épuisement. Nous devons toujours veiller à garder notre capacité de voir le verre à moitié plein plutôt qu'à moitié vide, et peut-être avoir une partie de l'optimisme que nos étudiantes nous transmettent. Au début de leur carrière, les étudiantes voient un monde plein de possibilités, ce qui est un point de vue rafraîchissant. Je crois que la priorité, et la façon d'être créative, optimiste et ayant une attitude de réussite, est de conserver notre curiosité et de continuer à apprendre pendant toute notre vie. Lorsque nous apprenons, nous ressentons un sens de l'accomplissement et un goût d'avancer. Nous sommes chanceuses de pouvoir travailler dans des établissements ou lieux d'apprentissage. Une autre priorité sur laquelle nous devrons nous concentrer sera de surmonter tous les conflits, dont ceux qui créent des divisions au sein du corps professoral où certaines personnes semblent plus appréciées que d'autres. Leurs responsabilités peuvent être différentes et certaines peuvent sembler moins importantes que d'autres. Je crois que ce sentiment existe aussi dans le milieu de la santé, particulièrement dans la vision que les infirmières 
cliniciennes ont des infirmières enseignantes et viceversa; il en est de même avec l'équipe soignante: comment les infirmières se sentent lorsqu'elles travaillent avec des enseignantes ou cliniciennes d'autres disciplines? Si nous n'essayons pas de croire en nous-mêmes et d'aider les autres, les étudiantes et les diplômées, à faire de même tout en gardant une dose d'humilité, notre énergie est minée. Si vous êtes impliquée dans une activité et que vous n'arrivez pas à atteindre de bons résultats, que vous êtes incapable d'avancer, vous oubliez à quel point les choses peuvent être intéressantes, créatives et belles. Vous vous enfoncez dans la torpeur et votre énergie vous abandonne. Voilà donc le défi : comment garder la flamme allumée et comment travailler ensemble afin d'être efficaces et en cohésion. Ce sont des défis de taille.

$D^{\text {re }}$ Myrick : Voilà une phrase des plus pertinentes pour terminer notre entrevue. Merci d'avoir su nous éclairer sur le leadership en formation des sciences infirmières. 